\title{
AzaHx, a Novel Fluorescent, DNA Minor Groove and G•C Recognition Element: Synthesis and DNA Binding Properties of a $p$-Anisyl-4-aza-benzimidazole- pyrrole-imidazole (azaHx-PI) Polyamide
}

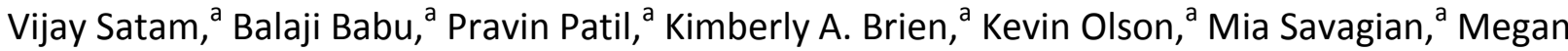 \\ Lee, ${ }^{a}$ Andrew Mepham, ${ }^{a}$ Laura Beth Jobe, ${ }^{b}$ John P. Bingham, ${ }^{c}$ Luke Pett, ${ }^{c}$ Shuo Wang, ${ }^{d}$ Maddi \\ Ferrara, ${ }^{\mathrm{e}}$ Chrystal D. Bruce, ${ }^{\mathrm{e}}$ W. David Wilson, ${ }^{\mathrm{d}}$ Moses Lee, ${ }^{*}, \mathrm{a}, \mathrm{d}$ John A. Hartley, ${ }^{\mathrm{c}}$ Konstantinos \\ Kiakos $^{c}$ \\ ${ }^{a}$ Department of Chemistry, Hope College, Holland, MI, 49423 \\ ${ }^{b}$ Department of Chemistry, Erskine College, Due West, SC, 29639 \\ ${ }^{c}$ Cancer Research UK Drug-DNA Interactions Research Group, UCL Cancer Institute, London \\ WC1E 6BT, UK \\ ${ }^{d}$ Department of Chemistry, Georgia State University, Atlanta, GA 30303 \\ ${ }^{e}$ Department of Chemistry, John Carroll University, University Heights, $\mathrm{OH} 44118$
}

*Corresponding author's present address: Georgia State University. Tel.: +1 360949 6310; fax: +1 360694 1819. E-mail address: mosesleenf@gmail.com (M. Lee).

\begin{abstract}
:
The design, synthesis, and DNA binding properties of $a z a \mathrm{Hx}-\mathrm{PI}$ or $p$-anisyl-4-aza-benzimidazolepyrrole-imidazole (5) are described. $A z a \mathrm{Hx}, 2-(p$-anisyl)-4-aza-benzimidazole-5-carboxamide, is a novel, fluorescent DNA recognition element, derived from Hoechst 33258 to recognize $\mathrm{G} \bullet \mathrm{C}$ base pairs. Supported by theoretical data, the results from DNase I footprinting, $C D, \Delta T_{M}$, and SPR studies provided evidence that an $a z a \mathrm{Hx} / \mathrm{IP}$ pairing, formed from antiparallel stacking of two azaHx-PI molecules in a side-by-side manner in the minor groove, selectively recognized a C-G doublet. AzaHx-PI was found to target 5'-ACGCGT-3', the Mlu1 Cell Cycle Box (MCB) promoter sequence with specificity and significant affinity $\left(K_{\text {eq }} 4.0 \pm 0.2 \times 10^{7} \mathrm{M}^{-1}\right)$.
\end{abstract}

Keywords: AzaHx, Hx-amides, DNA, Sequence recognition, Minor groove, Distamycin, Polyamides, Hoechst 33258

The design of small molecules capable of entering cells, concentrating in the nucleus, recognizing specific DNA sequences, and affecting gene expression continues to be at the forefront of life sciences and medical research. ${ }^{1}$ One class of DNA, minor groove and sequence selective binding molecules that continues to receive significant attention is the imidazole (I) and pyrrole (P) polyamide analogs of distamycin 1 (Figure 1) and netropsin. ${ }^{2}$ It has been shown that replacement of the pyrrole moiety of distamycin with imidazole, which contains a nitrogen atom on the DNA facing-side of the molecule, is capable of accommodating the guanine-2amino group that protrudes from the floor of the minor groove, and forming a hydrogen bond. This structural modification has enabled the polyamides, which bind as an antiparallel, side-by- 
side, stacked dimer, to target DNA base pairs. Specifically, a P/P pairing binds to either an $A / T$ or T/A base pair, an I/P pairing binds $\mathrm{G} / \mathrm{C}$, a $\mathrm{P} / \mathrm{I}$ pairing binds $\mathrm{C} / \mathrm{G}$, and the positively charged $\mathrm{C}$ terminus binds to either $A / T$ or $T / A$. Dervan's group has introduced the hydroxypyrrole to further distinguish between an $A / T$ or a $T / A$ base pair. However, due to the difficulty in the synthesis and stability of hydroxypyrrole, it has not been widely used. ${ }^{3}$ Our group has reported that the formamido group of distamycin behaved similarly to a pyrrole moiety in terms of sequence recognition, and it conferred enhanced binding affinity over its non-formamidopyrrole counterpart. ${ }^{4}$ Furthermore, the I/I pairing was reported by us to target the $\mathrm{T} / \mathrm{G}$ or $\mathrm{G} / \mathrm{T}$ mismatched base pair, although it could also tolerate either a $\mathrm{G} / \mathrm{C}$ or $\mathrm{C} / \mathrm{G}$ base pair. ${ }^{5}$ As examples of sequence specific polyamides, f-IPI $2^{6}$ and PIPI $3^{6 \mathrm{~d}}$ bind specifically to $5^{\prime}$-ACGCGT$3^{\prime}$, which corresponds to the Mlu1 Cell Cycle Box (MCB) sequence found in the control region of the human Dbf4 gene promoter. Expression of the Dbf4 gene is essential for the growth of several human cancers. ${ }^{7}$

[FIGURE 1]

Polyamides have been investigated extensively for their biological activity, including the control of gene expression in cells and anticancer activity in vivo. Some encouraging results have been reported recently; ${ }^{8}$ however, challenges remain in moving the field forward. These include the need to develop molecules that are of low molecular weight, yet demonstrate sequence specificity, high binding affinity, and good water solubility. In addition, these molecules must readily enter the nucleus and efficiently block gene expression in cells. In order to study nuclear uptake an added advantage would be to develop molecules that are inherently fluorescent so they can be directly observed by microscopy. To address these challenges our group has developed a novel class of small diamino polyamides that contain orthogonal aminoalkyl groups on the N1 positions of $\mathrm{P}$ or I. ${ }^{9}$ These diamino polyamides exhibited high DNA binding affinity, sequence specificity, water solubility, and propensity to enter cells. Our group is also addressing the issue of fluorescence by introducing the $\mathrm{Hx}$ moiety, 2-( $p$-anisyl)benzimidazole-5carboxamide).$^{10}$ Hybrids of $\mathrm{Hx}$ with $\mathrm{P}$ and I-polyamides, called $\mathrm{Hx}$-amides, were found to bind in a side-by-side, stacked, and antiparallel manner in the minor groove. Hx spans two base pairs, and pairing it with $\mathrm{P}$ and I-polyamides was found to recognize DNA base pairs in a predictable manner in which $\mathrm{Hx}$ mimicked two consecutive pyrrole units "P-P" or formamido-pyrrole " $\mathrm{f}$ $\mathrm{P}^{\prime \prime} .{ }^{10}$ As an example, Hx-IP 4 binds selectively to $5^{\prime}-\mathrm{A} / \mathrm{T}-\mathrm{A} / \mathrm{T}-\mathrm{C}-\mathrm{G}-\mathrm{A} / \mathrm{T}-\mathrm{A} / \mathrm{T}-3^{\prime}$ (see Figure $2 \mathrm{~A}$ ), including 5'-TACGAT- $3^{\prime}$, a sequence located in the $5^{\prime}$-flank of the Inverted CCAAT Box-2 (ICB-2) promoter site of the human topoisomerase Il $\alpha$ gene. $\mathrm{Hx}-\mathrm{IP}$ is able to block the binding of the repressive transcriptional factor NF-Y to ICB-2 thereby activating the expression of the topoisomerase ll $\alpha$ gene in confluent cancer cells. ${ }^{11}$

In this communication, we report the design of a second generation $\mathrm{Hx}$-amide that contains the novel azaHx moiety, which should mimic the DNA binding properties of a "P-1" or "f-l" unit. This should expand the ability of $\mathrm{Hx}$-amides to recognize $\mathrm{G} / \mathrm{C}$ containing sequences. With its resemblance to $\mathrm{Hx}^{10}{ }^{10}$ Hoechst $33258,{ }^{12}$ and related benzimidazole structures, ${ }^{13}$ the $a z a \mathrm{Hx}$ moiety should be fluorescent upon UV excitation. Interestingly, it has also been recently reported that groups with nitrogen acceptors, such as azabenzimidazole in azaHx and pyridine, 
when added to classical AT specific cationic heterocyclic compounds can confer GC binding selectivity on those compounds as with the polyamides reported here. ${ }^{14}$ It is clear that a new generation of fluorescent minor groove binding compounds is possible with substitutions of this type. To test these ideas, the synthesis of $a z a \mathrm{Hx}-\mathrm{PI} \mathbf{5}$ was undertaken and reported herein. According to the DNA binding model of $a z a \mathrm{Hx}$-PI $\mathbf{5}$ in the minor groove of DNA, depicted in Figure $2 B$, its dimer is predicted to bind the MCB sequence $5^{\prime}$-ACGCGT- 3 ' in a similar manner as f-IPI $2^{6}$ and PIPI $3^{6 d}$

[FIGURE 2]

As depicted in Scheme 1, azaHx-PI 5 was synthesized by coupling of 2-(p-anisyl)-4-azabenzimidazole-5-carboxylic acid $\mathbf{6}^{15}$ with amino-PI- $N, N$-dimethyl-2-aminoethylamine $7^{6 a}$ in anhydrous dimethylformamide, and in the presence of $\mathrm{EDCl}$, hydroxybenzotriazole, and triethylamine at room temperature. Purification of the crude product by silica gel column chromatography gave the desired product as a yellow solid in $21 \%$ yield, which was characterized by TLC, infrared, $400 \mathrm{MHz}{ }^{1} \mathrm{H}-\mathrm{NMR}$, and mass spectrometry. ${ }^{16}$

\section{[SCHEME 1]}

The sequence specificity of azaHx-PI 5 for 5'-ACGCGT-3' was ascertained by DNase I footprinting experiments using a $5^{\prime}-{ }^{32} \mathrm{P}$ labeled 175 base pair DNA fragment that contained the cognate sequence of $5^{\prime}$-ACGCGT-3'. Also included in the resolved region of the gel given in Figure 3 are four other non-cognate sequences to challenge the DNA sequence selectivity of $a z a \mathrm{Hx}$-amide 5. The results revealed a clear footprint for the cognate sequence, emerging at 0.5 $\mu \mathrm{M}$. The results also indicated that up to $10 \mu \mathrm{M}$, no diminution of the bands was observed for the other sites suggesting a preference of $a z a \mathrm{Hx}$-PI $\mathbf{5}$ for its target sequence. In a separate study (data not shown) performed on the same DNA fragment, no other footprints beyond the cognate sequence were observed even at $20 \mu \mathrm{M}$ of $a z a \mathrm{Hx}-\mathrm{PI}$, suggesting that the selectivity factor is at least 40 fold. For comparison, in terms of binding affinity, f-IPI $\mathbf{2}$ and PIPI $\mathbf{3}$ produced a footprint at $0.05 \mu \mathrm{M}$ and $1 \mu \mathrm{M}$, respectively, for the same cognate sequence on the same

DNA fragment used in this study. ${ }^{6 \mathrm{~b}-\mathrm{e}}$ With regard to sequence selectivity, at $1 \mu \mathrm{M}$ or a 20 -fold higher in concentration, a footprint for f-IPI 2 at 5'-AGCGCT-3' appeared, suggesting that even though $\mathrm{f}$-IPI binds DNA more strongly than $a z a \mathrm{Hx}$-amide $\mathbf{5}$ it is less sequence selective. The DNA sequence selectivity of PIPI $\mathbf{3}$ is more comparable to $a z a \mathrm{Hx}-\mathrm{PI}$. Overall, it appears that aza Hx-PI $\mathbf{5}$ is optimal in terms of strong binding affinity and sequence specificity when compared to polyamides $\mathbf{2}$ and $\mathbf{3}$.

\section{[FIGURE 3]}

The binding of azaHx-PI 5 to its cognate 5'-ACGCGT-3' sequence was further investigated by biophysical methods. DNA thermal denaturation studies performed on hairpin oligomers containing either the cognate sequence or 5'-ACCGGT-3' or 5'-AAATTT-3' (3 $\mu \mathrm{M}$ ligand and $1 \mu \mathrm{M}$ DNA, $10 \mathrm{mM}$ sodium phosphate, $1 \mathrm{mM}$ EDTA, $\mathrm{pH}$ 6.2) gave $\Delta \mathrm{T}_{\mathrm{M}}$ values of 17,7 , 
and $5{ }^{\circ} \mathrm{C}$, respectively. The results from the DNA denaturation studies of ligand $\mathbf{5}$ with $5^{\prime}$ ACGCGT-3' are given in Figure 4A. Figure 4B depicts the CD titration studies of 5 with its cognate sequence ( $160 \mu \mathrm{L}$ of a $9 \mu \mathrm{M}$ DNA hairpin solution in $10 \mathrm{mM}$ sodium phosphate, $\mathrm{pH}$ 6.2, titrated with 0.5 mol equiv. of 5.) As is typical for polyamide and $\mathrm{Hx}$-amide minor groove binding agents, ${ }^{4-6,9,10}$ titration of ligand $\mathbf{5}$ to the DNA solution produced a strong DNA-induced ligand band at about $355 \mathrm{~nm}$, and a clear isodichroic point was observed at about $335 \mathrm{~nm}$. Furthermore, the magnitude of the DNA-induced ligand band reached a plateau at about a ratio of 2:1 mol of ligand to DNA, suggesting that ligand $\mathbf{5}$ interacted in the minor groove as a sideby-side dimer. The sequence specificity of azaHx-amide 5 further suggested that stacking of the molecules in the minor groove was in an antiparallel fashion. Because Hx and Hoechst 33258 are fluorescent, the fluorescent enhancement of $a z a \mathrm{Hx}-\mathrm{PI} 5(0.5 \mu \mathrm{M})$ upon binding to the $5^{\prime}$ ACGCGT-3' hairpin was measured. As shown in Figure 4C, upon excitation at $320 \mathrm{~nm}$, based on the UV-vis spectrum of 5 in $10 \mathrm{mM}$ sodium phosphate, $\mathrm{pH} \mathrm{6.2,} \mathrm{a} \mathrm{distinct} \mathrm{emission} \mathrm{at} \mathrm{about} 410$ $\mathrm{nm}$ was detected for the ligand alone. Consistent with the earlier reported Hx-amide Hx-IP, addition of 3 mol equiv. of the DNA hairpin to the buffered solution of $\mathbf{5}$ almost doubled the fluorescence. The binding affinity of $a z a \mathrm{Hx}-\mathrm{PI} 5$ to its cognate sequence was determined by SPR studies using a hairpin oligomer that contains the core 5-'ACGCGT-3' sequence. According to the sensograms depicted in Figure 4D, it was evident that the association rate of ligand $\mathbf{5}$ on the DNA was generally slow and the rate increased with higher concentrations. However, as is typical for strongly binding minor groove binders, the dissociation rate was extremely slow and independent of ligand concentration. Fitting of the steady-state RU (response unit) versus concentrations using a two-site model, the binding constant for the binding of ligand 5 to $5^{\prime}$ ACGCGT-3' was $4.0 \pm 0.2 \times 10^{7} \mathrm{M}^{-1}$ with a standard error for the fit. This value was similarly lower than the binding of $\mathrm{f}-\mathrm{IPI} 2$ to the same DNA sequence $\left(1.9 \times 10^{8} \mathrm{M}^{-1}\right)$, ${ }^{6-c}$ and was consistent with the results from the abovementioned DNase I footprinting.

\section{[FIGURE 4]}

To ascertain the DNA recognition properties of $a z a \mathrm{Hx}$ as a fluorescent surrogate of "P-I", molecular modeling studies of azaHx-carboxamide and $\mathrm{PI}$-carboxamide were performed using a procedure previously reported by our group. ${ }^{10 a}$ Geometry optimizations and calculations of the electrostatic surface potential and dipole moments of the two molecules were performed using Gaussian $09^{17}$ at the B3LYP level of theory with the $6-311+G(d, p)$ basis set. WebMO ${ }^{18}$ was used as the interface for performing the calculations and viewing the output. Based on the molecular electrostatic potential of PI-carboxamide and azaHx-carboxamide (Figures 5A and 5B), it was evident that $a z a \mathrm{Hx}$ had the same shape, the same distribution of positive and negative electrostatic potential, and the same direction of the dipole moment as "P-I". However, the dipole moments for $\mathrm{PI}$-carboxamide and $a z a \mathrm{Hx}$-carboxamide were calculated to be 2.3 Debye (Figure 5C) and 6.8 Debye (Figure 5D), respectively. The larger dipole moment of azaHxcarboxamide could explain why azaHx-PI 5 interacted 26 times more strongly with the same cognate sequence $5^{\prime}$-ACGCGT-3' than polyamide PIPI 3 according to SPR $\left(4.0 \pm 0.2 \times 10^{7} \mathrm{M}^{-1}\right.$ versus $\left.7.1 \times 10^{6} \mathrm{M}^{-1}\right)^{6 \mathrm{~d}}$ and the DNase I footprinting studies.

[FIGURE 5] 
In conclusion, the results from the DNase I footprinting, biophysical, and theoretical studies of $a z a \mathrm{Hx}$-PI 5 are consistent with the DNA binding properties of $\mathrm{f}-\mathrm{IPI} \mathbf{2}^{6}$ and PIPI 3 . $^{6 \mathrm{~d}}$ The results also confirmed that $a z a \mathrm{Hx}$ is a novel, fluorescent, "P-I" or "f-I" recognition element available for the design of tractable, sequence specific, DNA minor groove binding agents. $A z a \mathrm{Hx}$ does not only add to the repertoire of DNA recognition heterocycles in polyamides and $\mathrm{Hx}$-amides, it also endows the molecules with the ability to fluoresce and aid biological studies.

\section{Acknowledgements}

The authors thank the NSF (CHE 0809162), Cancer Research UK (C2259/A16569), and the Georgia Research Alliance for support of this research.

\section{References and notes}

1. (a) Pett, L.; Hartley, J. A.; Kiakos, K. Curr. Topics Med. Chem. 2015, in press. (b) Cai, X.; Gray, P. J. Jr.; Von Hoff, D. D. Cancer Treat. Rev. 2009, 35, 437. (c) Khan, G. S.; Shah, A.; Rehman, Z.-A.; Barker, D. J. Photochem. Photobiol. B: Biology 2012, 115, 105. (d) Tietjen, J. R.; Donato, L. J., Bhimisaria, D.; Ansari, A. Z. Methods Enzymol. 2011, 497, 3.

2. (a) Blackledge, M. S.; Melander, C. Bioorg. Med. Chem. 2013, 21, 6101. (b) Erwin, G. S.; Bhimsaria, D.; Eguchi, A.; Ansari, A. Z. Angew. Chem. Int. Ed. 2014, 53, 1.

3. Dervan, P. B. Bioorg. Med. Chem. 2001, 9, 2215

4. (a) Lacy, E. R.; Le, N. M.; Price, C. A.; Lee, M.; Wilson, D. W. J. Am. Chem. Soc. 2002, 124, 2153. (b) Collar, C. J.; Lee, M.; Wilson, W. D. J. Chem. Inf. Model. 2010, 50, 1611.

5. (a) Yang, X-L.; Hubbard IV, R. B.; Lee, M.; Tao, Z-H.; Sugiyama, H.; Wang, A. H-J. Nucl. Acids Res. 1999, 27, 4183. (b) Lacy, E. R.; Cox, K. K.; Wilson, W. D.; Lee, M. Nucleic Acids Res. 2002, 30, 1834. (c) Lacy, E. R.; Nguyen, B.; Le, M.; Cox, K. K.; Ohare, C.; Hartley, J. A.; Lee. M.; Wilson, W. D. Nucleic Acids Res. 2004, 32, 2000. (d) Rucker, V. C.; Foister, S.; Melander, C.; Dervan, P. B. J. Am. Chem. Soc. 2003, 125, 1195.

6. (a) Buchmueller, K. L.; Staples, A. M.; Howard, C. M.; Horick, S. M.; Uthe, P. B.; Le, N. M.; Cox, K. K.; Nguyen, B.; Pacheco, K. A.; Wilson, W. D.; Lee, M. J. Am. Chem. Soc. 2005, 127, 742. (b) Buchmueller, K. L.; Staples, A. M.; Uthe, P. B.; Howard, C. M.; Pacheco, K. A. O.; Cox, K. K.; Henry, J. A.; Bailey, S. L.; Horick, S. M.; Nguyen, B.; Wilson, W. D.; Lee, M. Nucl. Acids Res. 2005, 33, 912. (c) Buchmueller, K. L.; Bailey, S. L.; Matthews, D. A.; Taherbhai, Z. T.; Register, J. K.; Davis, Z. S.; Bruce, C. D.; O'Hare, C.; Hartley, J. A.; Lee, M. Biochemistry 2006, 45, 13551. (d) Brown, T.; Mackay, H.; Turlington, M.; Sutterfield, A.; Smith, T.; Sielaff, A.; Westrate, L.; Bruce, C.; Kluza, J.; O'Hare, C.; Nguyen, B.; Wilson, W. D.; Hartley, J. A.; Lee, M. Bioorg. Med. Chem. 2008, 16, 5266. (e) Lin, S.; Kiakos, K.; Lee, M.; Hochhauser, D.; Hartley, J. A. Proc. Am. Assoc. Cancer Res. 2011, abstract 665. 
7. (a) Wu, X.; Lee, H. Oncogene 2002, 21, 7786. (b) Knockleby, J. W.; Romero, J.; Kylie, K. A.; Lee, H. Curr. Top. Biochem. Res. 2010, 12, 43. (c) Charych, D. H.; Coyne, M.; Yabannavar, A.; Narberes, J.; Chow, S.; Wallroth, M.; Shafer, C.; Walter, A. O. J. Cell Biochem. 2008, 104, 1075. (d) Bonte, D.; Lindvall, C.; Liu, H.; Dykema, K.; Furge, K.; Weinreich, M. Neoplasia 2008, 10, 920. (e) Sheu, Y.J.; Stillman, B. Nature 2010, 463, 113.

8. (a) Raskatov, J. A.; Szablowski, J. O.; Dervan, P. B. J. Med. Chem. 2014, 57, 8471. (b) Martinez, T. F.; Phillips, J. W.; Karanja, K. K.; Polaczek, P.; Wang, C-M.; Li, B. C.; Campbell, J. L.; Dervan, P. B. Nucleic Acids Res. 2014, 42, 11546. (c) Raskatov, J. A.; Puckett, J. W.; Dervan, P. B. Bioorg. Med. Chem. 2014, 22, 4371. (d) Kang, J. S.; Meier, J. L.; Dervan, P. B. J. Am. Chem. Soc. 2014, 136, 3687. (e) Nickols, N. G.; Li, B. C.; Szablowski, J. O.; Hamilton, S. R.; Meier, J. L.; Wang, C-M.; Dervan, P. B. J. Med. Chem. 2013, 56, 7449.

9. (a) Babu, B.; Liu, Y.; Plaunt, A.; Riddering, C.; Ogilvie, R.; Westrate, L.; Davis, R.; Ferguson, A.; Mackay, H.; Rice, T.; Chavda, S.; Wilson, D.; Lin, S.; Kiakos, K.; Hartley, J. A.; Lee, M. Biochem. Biophys. Res. Commun. 2011, 404, 848. (b) Satam, V.; Babu, B.; Porte, A.; Savagian, M.; Lee, M.; Smeltzer, T.; Liu, Y.; Ramos, J.; Wilson, W. D.; Lin, S.; Kiakos, K.; Hartley, J. A.; Lee, M. Bioorg. Med. Chem. Lett. 2012, 22, 5898. (c) Satam, V.; Babu, B.; Chavda, S.; Savagian, M.; Sjoholm, R.; Tzou, S.; Liu, Y.; Kiakos, K.; Lin, S.; Wilson, D. W.; Hartley, J. A.; Lee, M. Bioorg. Med. Chem. 2012, 20, 693.

10. (a) Chavda, S.; Liu, Y.; Babu, B.; Davis, R.; Sielaff, A.; Ruprich, J.; Westrate, L.; Tronrud, C.; Ferguson. A.; Franks, A.; Tzou, S.; Adkins, C.; Rice, T.; Mackay, H.; Kluza, J.; Tahir, S. A.; Lin, S.; Kiakos, K.; Bruce, C. D.; Wilson, W. D.; Hartley, J. A.; Lee, M. Biochemistry 2011, 50, 3127. (b) Satam, V.; Babu, B.; Gregory, M.; Bowerman, M.; Savagian, M.; Lee, M.; Tzou, S.; Liu, Y.; Ramos, J.; Wilson, W. D.; Lin, S.; Kiakos, K.; Hartley, J. A.; Lee, M. Bioorg. Med. Chem. Lett. 2013, 23, 1699.

11. (a) Kiakos, K.; Ruprich, J.; Davis, R.; Sielaff, A.; Westrate, L.; Tronrud, C.; Ferguson, A.; Brown, T.; Mackay, H.; Lee, M.; Liu, Y.; Wilson, D.; Hochhauser, D.; Hartley, J. A. Proc. Am. Assoc. Cancer Res. 2010, abstract 3521. (b) Kiakos, K.; Pett, L.; Satam, V.; Patil, P.; Hochhauser, D.; Lee, M.; Hartley, J. A. Chem. \& Biol. 2015, in press.

12. White, C. M.; Satz, A. M.; Bruice, T. C.; Beerman, T. A. Proc. Natl. Acad. Sci. U.S.A. 2001, 98, 10590.

13. (a) Renneberg, D.; Dervan, P. B. J. Am Chem. Soc. 2003, 125, 5707. (b) Bathini, Y.; Rao, E.; Shea, R. G.; Lown, J. W. Chem Res. Toxicol. 1990, 3, 268. (c) Chenoweth, D. M.; Viger, A.; Dervan, P. B. J. Am. Chem. Soc. 2007, 129, 2216.

14. (a) Chai, Y.; Paul, A.; Rettig, M.; Wilson, W. D.; Boykin, D. W. J Org Chem. 2014, 79, 852. (b) Paul, A.; Nanjunda, R.; Kumar, A.; Laughlin, S.; Nhili, R.; Depauw, S.; Deuser, S. S.; Chai, Yu.; Chaudhary, A. S.; David-Cordonnier, M-H, Boykin, D. W.; Wilson, W. D. Bioorg. \& Med. Chem. Lett. 2015, in press. 
15. The synthesis of 2-(p-anisyl)-4-aza-benzimidazole-5-carboxylic acid (azaHx-acid, 6) and related $\mathrm{Hx}$-acids analogs will be reported elsewhere.

16. AzaHx-acid 6 (0.052 g, $0.19 \mathrm{mmol})$ was dissolved in dry DMF (1.5 mL) and kept under nitrogen. $\mathrm{EDCl} . \mathrm{HCl}(0.11 \mathrm{~g}, 0.6 \mathrm{mmol})$ was added, followed by triethylamine $(0.11 \mathrm{~mL}, 0.8$ $\mathrm{mmol})$. After the solution was stirred for $5 \mathrm{~min}$ at room temperature, $\mathrm{HOBt}(0.087 \mathrm{~g}, 0.6 \mathrm{mmol})$ was added, and stirring was continued for another $5 \mathrm{~min}$ at room temperature. To the reaction mixture was added a solution of freshly prepared amino-PI intermediate 7, prepared from catalytic reduction of the corresponding nitro-PI precursor $(75 \mathrm{mg}, 0.21 \mathrm{mmol})$, in dry DMF $(2.0$ $\mathrm{mL}$ ) at room temperature. The reaction mixture was purged with nitrogen and stirred at room temperature for $16 \mathrm{~h}$. At which time the solvent was removed under reduced pressure (less than $50{ }^{\circ} \mathrm{C}$ at $0.1 \mathrm{~mm} \mathrm{Hg}$ ) and the crude residue was purified by column chromatography using silica gel and $7 \%$ methanol in chloroform to yield the $a z a \mathrm{Hx}-\mathrm{PI} 5$ as a yellow solid $(20 \mathrm{mg}, 21 \%$ ); $\mathrm{mp}: 155-157{ }^{\circ} \mathrm{C} ; \mathrm{R}_{\mathrm{f}}$ : 0.50 (1.5:0.2:8.3 v/v, $\left.\mathrm{CH}_{3} \mathrm{OH}: \mathrm{NH}_{4} \mathrm{OH} ; \mathrm{CHCl}_{3}\right)$; UV-vis ( $\mathrm{HCl}$ salt, water): $\lambda_{\max }$ $328 \mathrm{~nm}\left(\varepsilon=15,690 \mathrm{M}^{-1} \mathrm{~cm}^{-1}\right)$; FT-IR: 3231, 3211, 3161, 2956, 1634, 1530, 1434, 1362, 1228, 1108, 1019, 841, 792, $624 \mathrm{~cm}^{-1} ;{ }^{1} \mathrm{H}$ NMR: $\left(\mathrm{CD}_{3} \mathrm{OD}\right) \delta 8.16(\mathrm{~d}, \mathrm{~J}=8.0 \mathrm{~Hz}, 2 \mathrm{H}), 8.13(\mathrm{~d}, \mathrm{~J}=8.0 \mathrm{~Hz}, 1 \mathrm{H})$, $8.08(\mathrm{~d}, J=8.0 \mathrm{~Hz}, 1 \mathrm{H}), 7.89(\mathrm{~s}, 1 \mathrm{H}), 7.39(\mathrm{~s}, 1 \mathrm{H}), 7.17(\mathrm{~d}, J=8.0 \mathrm{~Hz}, 2 \mathrm{H}), 7.14(\mathrm{~s}, 1 \mathrm{H}), 4.02(\mathrm{~s}, 6 \mathrm{H})$, $3.91(\mathrm{~s}, 3 \mathrm{H}), 3.49(\mathrm{t}, \mathrm{J}=8.0 \mathrm{~Hz}, 2 \mathrm{H}), 2.59(\mathrm{t}, \mathrm{J}=6.0 \mathrm{~Hz}, 2 \mathrm{H}), 2.33(\mathrm{~s}, 6 \mathrm{H}) ; \mathrm{LRMS}\left(\mathrm{EI}^{+}\right) \mathrm{m} / \mathrm{z} 585\left(\mathrm{M}+\mathrm{H}^{+}\right.$, $52 \%) ; \mathrm{HRMS}[\mathrm{M}+\mathrm{H}]^{+}$calcd for $m / z \mathrm{C}_{29} \mathrm{H}_{33} \mathrm{~N}_{10} \mathrm{O}_{4}$ : 585.2686, obsd: 585.2676.

17. Frisch, M. J. Gaussian 09, Revision A.1; Gaussian, Inc.: Wallingford CT, 2009.

18. Schmidt, J. R., Polik, W. F. WebMO Enterprise, version 10.0. WebMO LLC: Holland, MI. Available from http://www.webmo.net (accessed January 2015). 


\section{Legends for Figures and Scheme}

Figure 1. Structures of distamycin 1, f-IPI 2, PIPI 3, Hx-IP 4, and azaHx-PI 5.

Figure 2. Binding of $\mathrm{Hx}-\mathrm{IP} 4$ and $a z a \mathrm{Hx}-\mathrm{PI} 5$ to their respective cognate DNA sequences.

Figure 3. Autoradiogram of DNase I footprinting experiment of azaHx-PI 5. Ligand and DNA were incubated for $1 \mathrm{~h}$ prior to enzyme digestion.

Figure 4. Binding of $a z a \mathrm{Hx}-\mathrm{PI} 5$ to $5^{\prime}$-ACGCGT-3' according to DNA thermal denaturation studies $(A), C D$ titrations (B), fluorescence (C), and SPR biosensor studies (D).

Figure 5. Molecular electrostatic surfaces of PI-carboxamide (A) and azaHx-carboxamide (B). Dipole moments of PI-carboxamide (C) and azaHx-carboxamide (D).

Scheme 1. Synthesis of azaHx-PI, 5. 

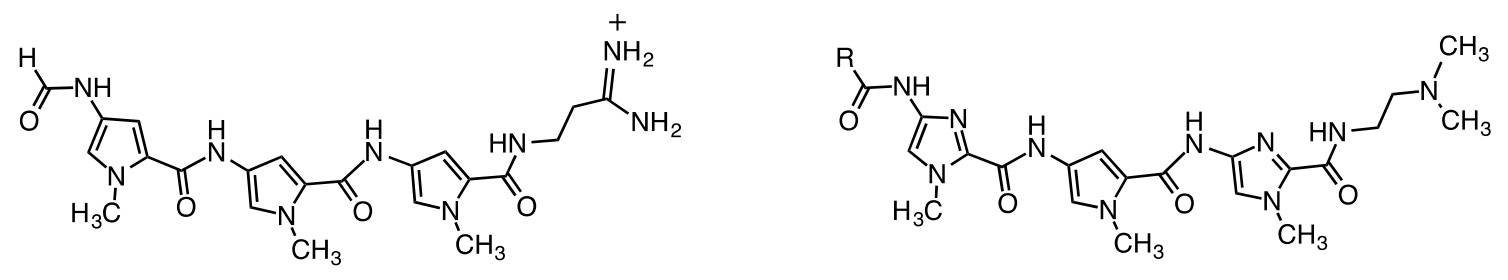

1

$$
\text { 2, } \mathrm{R}=\mathrm{H} \quad 3, \mathrm{R}=
$$

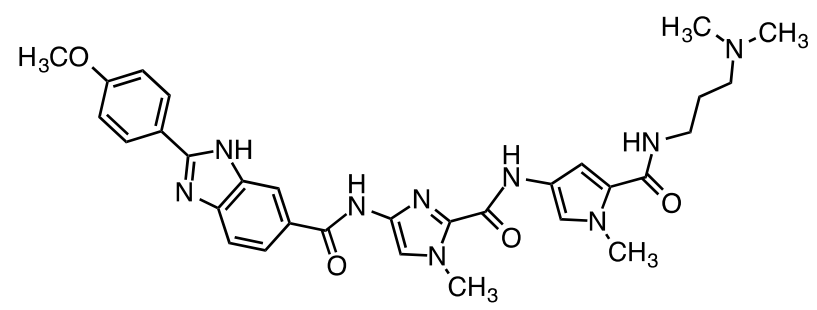

4

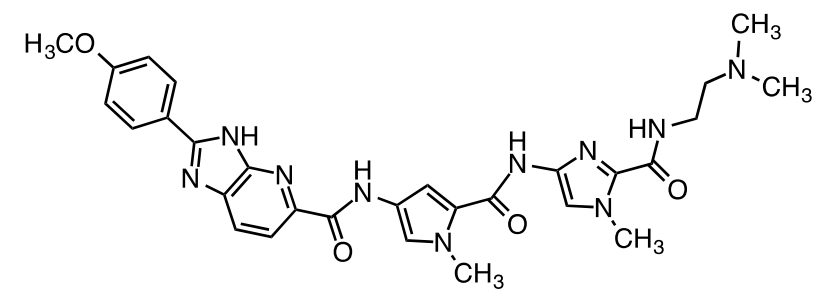

5

Figure 1 

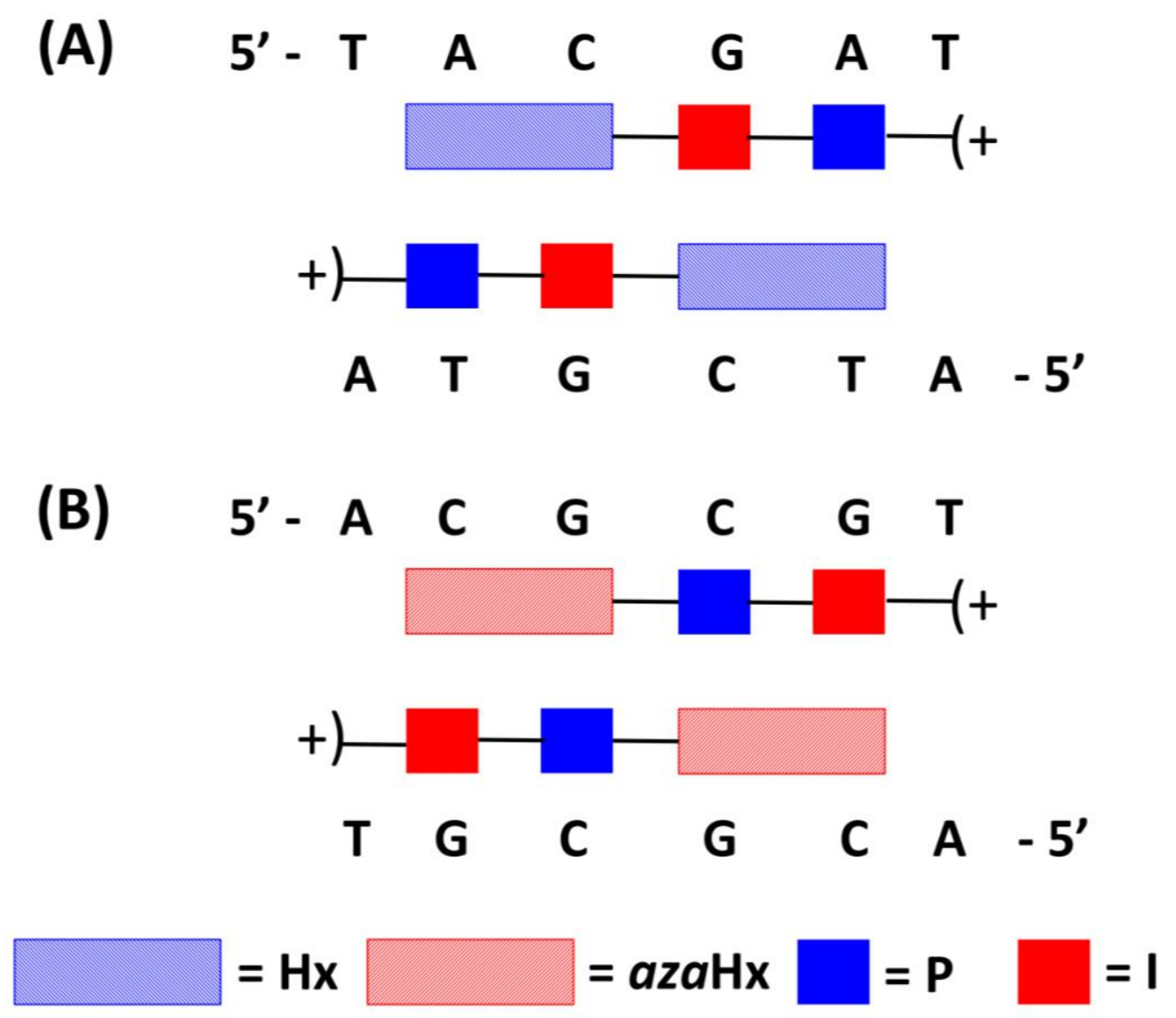

Figure 2 


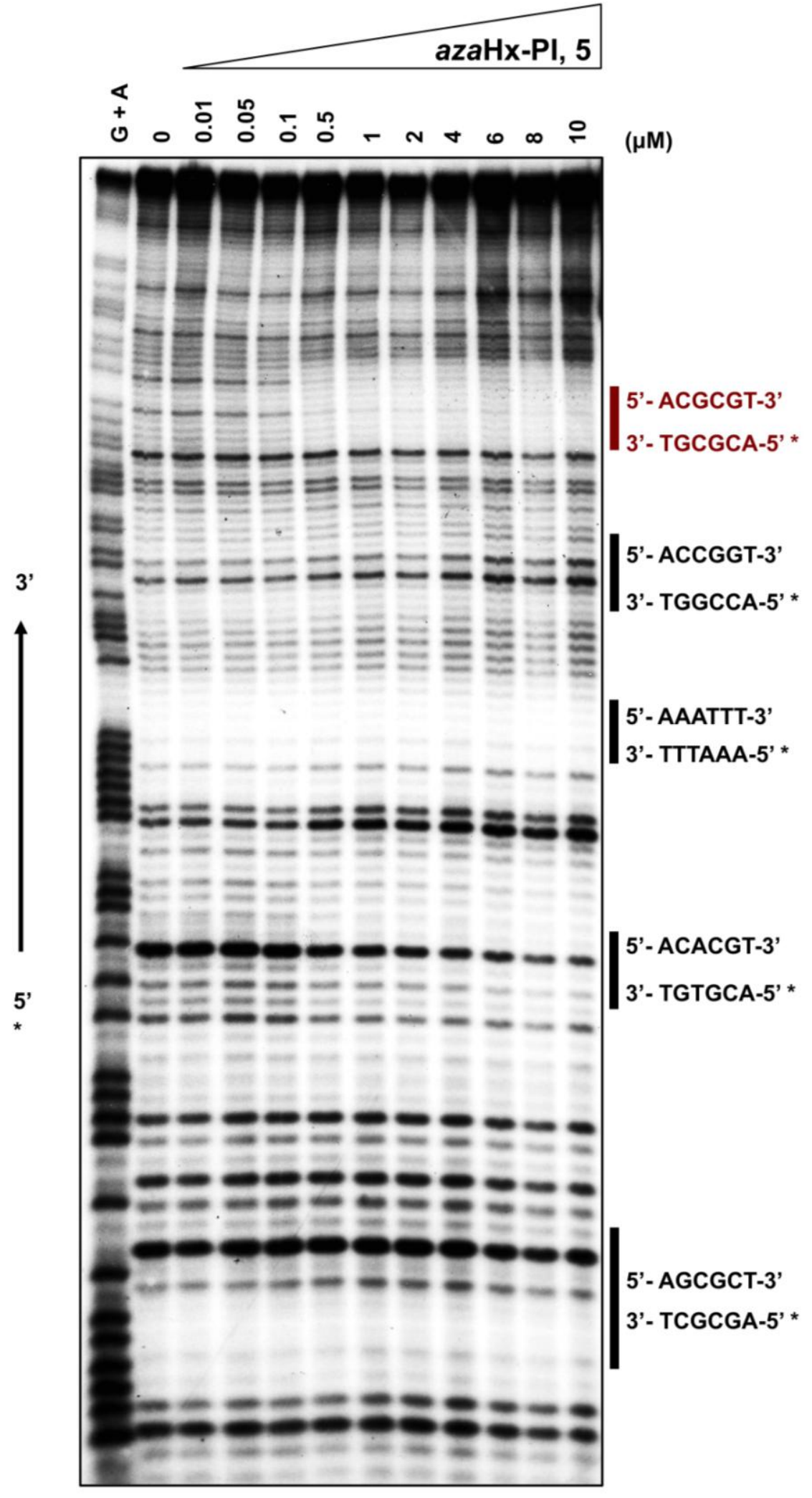

Figure 3 

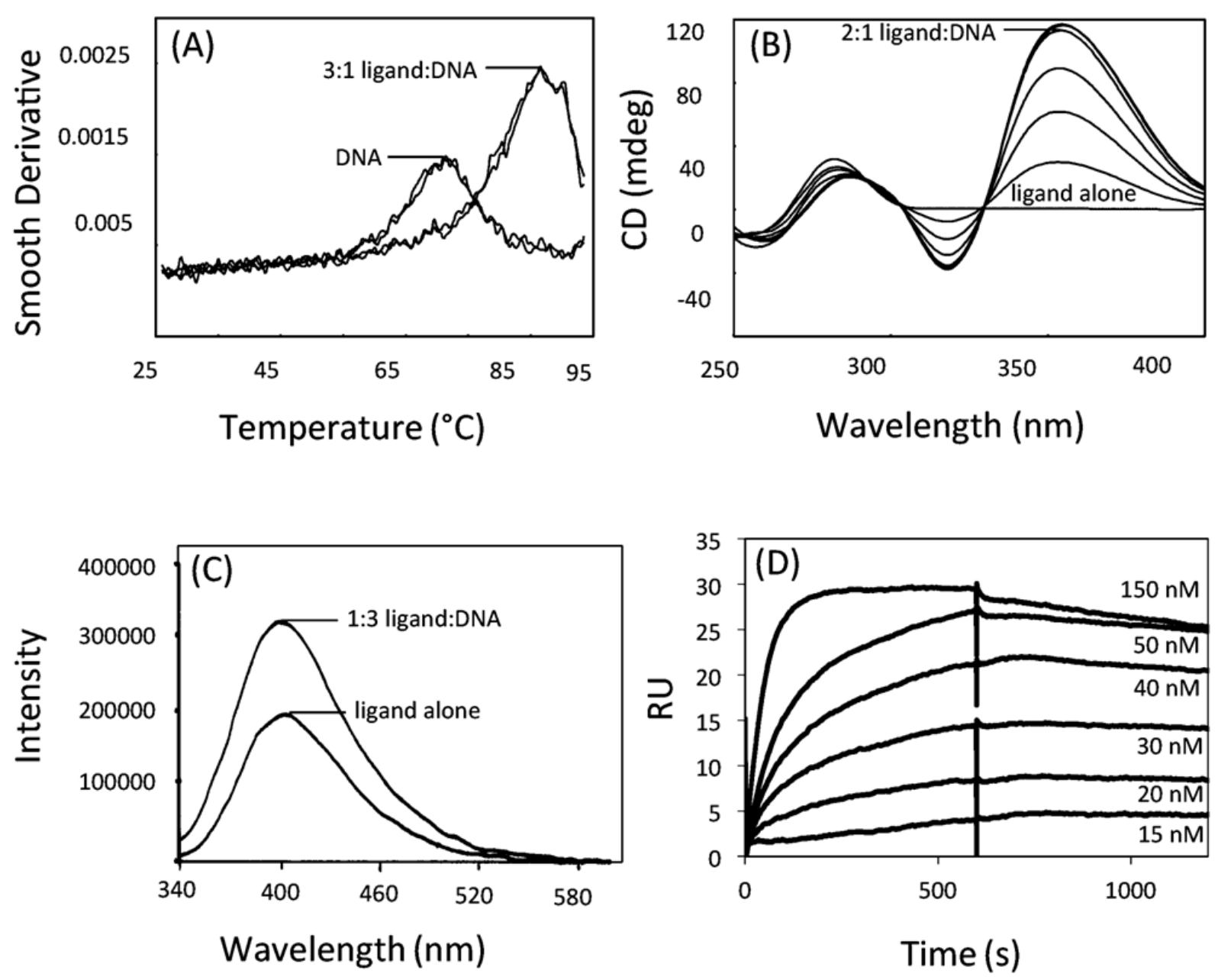

Figure 4 
(A)

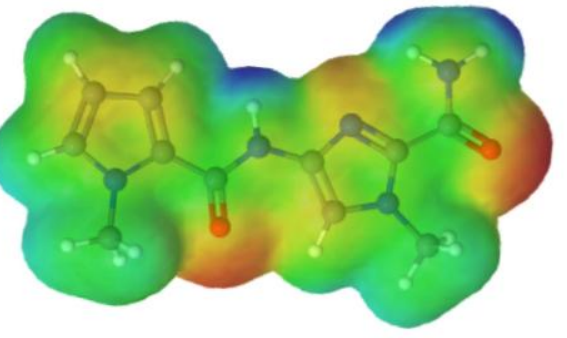

(C)

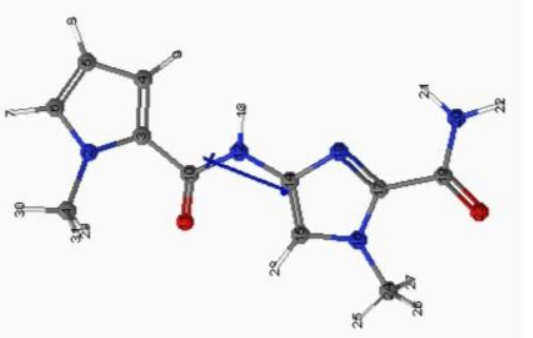

(B)

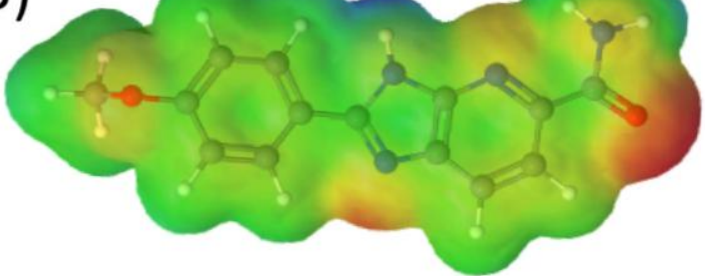

(D)

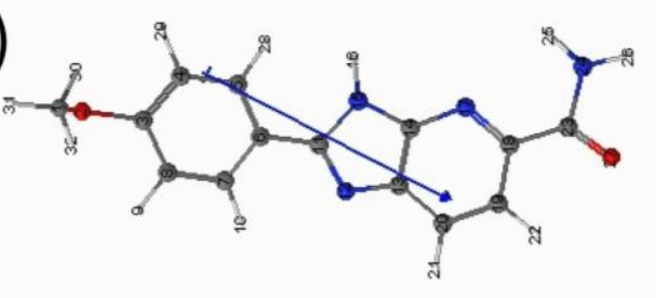

Figure 5 


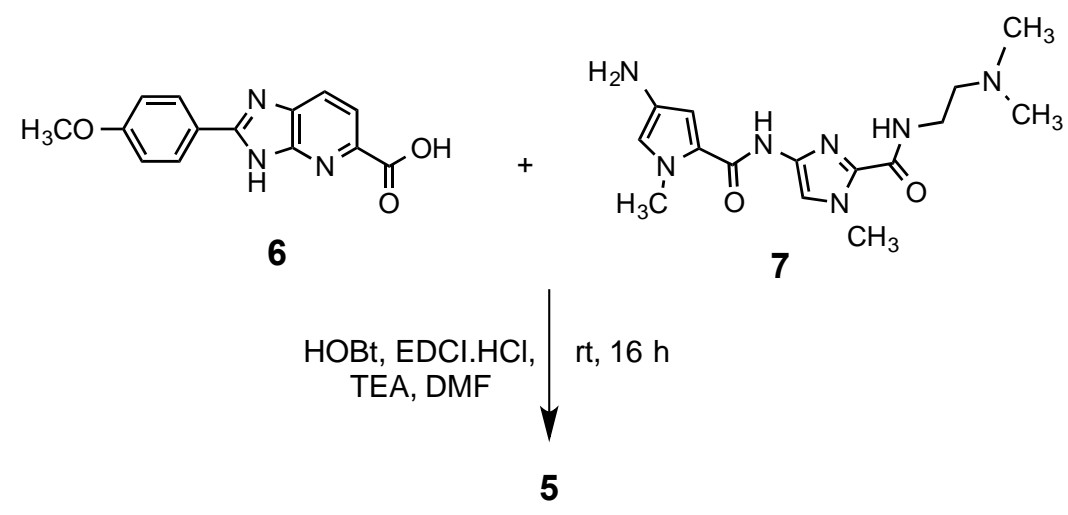

Scheme 1 
AzaHx, a Novel Fluorescent, DNA Minor Groove and G•C Recognition Element: Synthesis and DNA Binding Properties of a $p$-Anisyl-4-aza-benzimidazole-pyrrole-imidazole (azaHx-PI) Polyamide

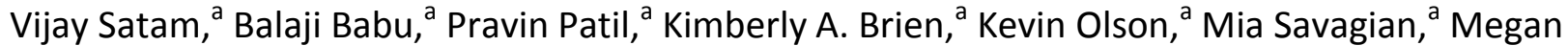
Lee, ${ }^{a}$ Andrew Mepham, ${ }^{a}$ Laura Beth Jobe, ${ }^{b}$ John P. Bingham, ${ }^{c}$ Luke Pett, ${ }^{c}$ Shuo Wang, ${ }^{d}$ Maddi

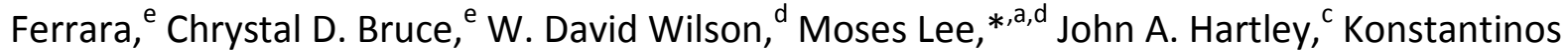
Kiakos $^{\mathrm{c}}$

\section{Graphical abstract}<smiles>CN(C)CCNC(=O)c1nc(NC(=O)c2cc(NC(=O)c3nc(NC(=O)c4cccn4C)cn3C)cn2C)cn1C</smiles>

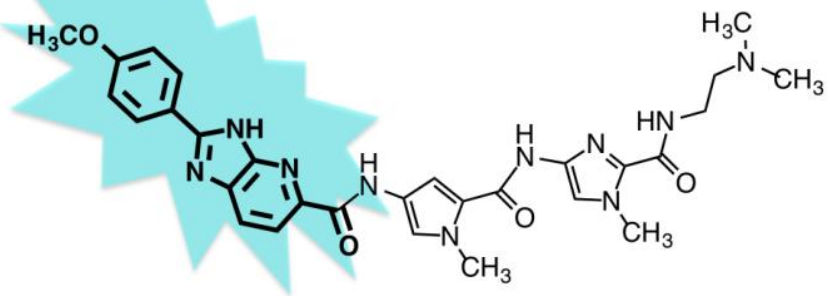

AzaHx-PI, 5
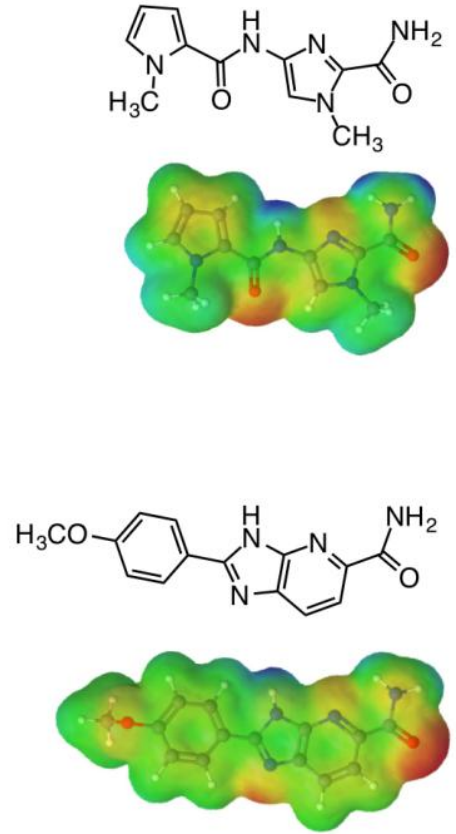